Meta

Journal des traducteurs

Translators' Journal

\title{
Dialogue, Reassurance and Understanding: Framing Political Translations during the 1980 and 1995 Quebec Sovereignty Referendums
}

\author{
Julie McDonough Dolmaya
}

Volume 59, numéro 3, décembre 2014

Traduction et plurilinguisme officiel

Translation and Official Multilingualism

URI : https://id.erudit.org/iderudit/1028658ar

DOI : https://doi.org/10.7202/1028658ar

Aller au sommaire du numéro

Éditeur(s)

Les Presses de l’Université de Montréal

ISSN

0026-0452 (imprimé)

1492-1421 (numérique)

Découvrir la revue

Citer cet article

McDonough Dolmaya, J. (2014). Dialogue, Reassurance and Understanding: Framing Political Translations during the 1980 and 1995 Quebec Sovereignty Referendums. Meta, 59(3), 578-597. https://doi.org/10.7202/1028658ar

\section{Résumé de l'article}

Au Canada, les années 1970, 1980 et 1990 ont donné lieu à la publication de plus de mille ouvrages - et une centaine de traductions - portant sur le nationalisme québécois, les mouvements indépendantistes ou les référendums sur la souveraineté, dans les deux langues officielles. Malgré la diversité de ces publications (biographies, analyses politiques, essais polémiques, ainsi de suite), presque tous ces ouvrages portaient sur des thèmes qui ont provoqué la controverse au Canada. Les paratextes qui se trouvent dans les traductions de ces textes sont donc une ressource importante qui éclaircit les différences perçues entre les opinions politiques des lecteurs anglophones et francophones. Cet article aura pour but d'analyser les paratextes dans les traductions anglaises et françaises de ces textes. On démontrera la façon dont les paratextes encourageaient les lecteurs du texte d'arrivée à lire la traduction d'un ouvrage qui n'était manifestement pas écrit pour eux et qui, parfois, était très critique envers eux. Enfin, on étudiera les caractéristiques partagées par les paratextes anglais et français, examinera les différences entre ces derniers, et tentera de déterminer pourquoi ces différences et ces similarités existent. 


\title{
Dialogue, Reassurance and Understanding: Framing Political Translations during the 1980 and 1995 Quebec Sovereignty Referendums
}

\author{
JULIE MCDONOUGH DOLMAYA \\ York University, Toronto, Canada \\ dolmaya@yorku.ca
}

\section{RÉSUMÉ}

Au Canada, les années 1970, 1980 et 1990 ont donné lieu à la publication de plus de mille ouvrages - et une centaine de traductions - portant sur le nationalisme québécois, les mouvements indépendantistes ou les référendums sur la souveraineté, dans les deux langues officielles. Malgré la diversité de ces publications (biographies, analyses politiques, essais polémiques, ainsi de suite), presque tous ces ouvrages portaient sur des thèmes qui ont provoqué la controverse au Canada. Les paratextes qui se trouvent dans les traductions de ces textes sont donc une ressource importante qui éclaircit les différences perçues entre les opinions politiques des lecteurs anglophones et francophones. Cet article aura pour but d'analyser les paratextes dans les traductions anglaises et françaises de ces textes. On démontrera la façon dont les paratextes encourageaient les lecteurs du texte d'arrivée à lire la traduction d'un ouvrage qui n'était manifestement pas écrit pour eux et qui, parfois, était très critique envers eux. Enfin, on étudiera les caractéristiques partagées par les paratextes anglais et français, examinera les différences entre ces derniers, et tentera de déterminer pourquoi ces différences et ces similarités existent.

\begin{abstract}
In Canada during the 1970s, 80s, and 90s, more than one thousand works - and about one hundred translations - were published on the topics of Quebec nationalism, independence movements, and sovereignty referendums, in both of Canada's official languages. Despite the diversity of these publications, which included biographies, political analyses, and polemical essays, almost all the works touched on themes that have generated controversy in Canada. The paratexts in these translations are therefore an important resource that highlight perceived differences between the political opinions of Francophone and Anglophone readers. This article will analyze the paratexts in the English and French translations to show how the target language audience was encouraged to read a translation of a work that was very clearly not addressed to them, and which in some cases even criticized the very audience it now addressed. Finally, it will examine which features these English and French paratexts do and do not share, while trying to determine why these similarities and differences exist.
\end{abstract}

\section{MOTS-CLÉS/KEYWORDS}

traduction politique, récits, paratextes, encadrement, politique canadienne political translation, narratives, paratexts, narrative frames, Canadian politics 


\section{Introduction}

In 1979, the Quebec government, led by Premier René Lévesque and the Parti Québécois, drafted a proposal for sovereignty-association and one year later called a provincial referendum that would allow Quebecers to vote on whether they accepted the terms for a sovereign Quebec economically associated with Canada as set forth in the proposal. On May 20, 1980, more than 85 percent of Quebecers voted to reject the proposal by a vote of approximately 60 to 40 percent.

The proposed changes to Canadian federalism could not be laid lightly aside however, and fifteen years later, on October 30, 1995, the Parti Québécois called a second referendum on a slightly different question. Quebecers were asked whether they wanted Quebec to become sovereign after the provincial government formally offered Canada a new economic and political partnership. Once more the proposal was rejected, though by a much smaller margin: approximately 51 to 49 percent. Between Yes and No voters was a significant linguistic divide: most of those whose first language was not French voted against sovereignty (Gill 1995: 418), while French speakers were divided. Though many Francophones supported constitutional change, they did not all agree that sovereignty was the best way to achieve this goal, and many were swayed to vote No on the expectation that fundamental constitutional change would result afterwards (Gill 1995: 410-416).

In the years leading up to the 1980 and 1995 Quebec independence referendums, hundreds of works were published in English and French discussing Quebec independence and arguing for and against renewed federalism, complete independence, and some form of sovereignty-association. A small number of these works were translated from one official language into the other. Frequently, the target-language readers were excluded from the original intended audience and, in some cases, were also the object of criticism. ${ }^{1}$ Since the source texts often addressed a different group of Canadians than the target texts, arguing in support of a political stance supported by very few in the target language communities or criticizing the group now reading the translation, these translations present an intriguing object of study.

The way target texts are interpreted by a target language (TL) audience will depend, to a certain extent, on how the translations are framed in introductions, prefaces or other paratextual material found within the target texts. To help determine the motives of publishers, editors or translators for producing or distributing the translation, this paper analyzes the new paratexts that were written specifically for the target texts. Many of these paratexts address the target audience in an effort to contextualize the translation or express support for one of the nationalist, federalist or independence-related causes. Often, they provide a variety of reasons why TL readers should be interested in reading a work that was not originally intended for or addressed to them. Exploring these reasons helps illustrate expectations about the target audience and reveals perceived differences between Canada's two official language groups.

\section{Corpus}

According to the Library and Archives Canada Catalogue, between 1968, the year the Parti Québécois was created, and 2000, the year the Clarity $A c t^{2}$ was passed, approximately 1,200 non-fiction works were published in English and French on the 
following three subjects: Autonomy and independence movements in Quebec, Quebec nationalism, and Quebec referendums. This figure includes a range of non-fiction works such as essays, biographies, and academic monographs with historical, political, and polemical themes, but it excludes novels, short story collections, plays, and poetry related to Quebec sovereignty and Francophone/Anglophone relations in Canada, which have already been the focus of Translation Studies research (for example, Brisset 1989; Ladouceur 2000; Mezei 1998). Also excluded from the corpus are audiovisual recordings and electronic media, as well as theses, bibliographies, conference proceedings, periodicals, and legal texts, which were deemed less relevant to this project.

Of the 1,200 works published during this period, approximately $70 \%$ were originally written in French and published nearly exclusively - with about a dozen exceptions - within Quebec. The remaining 30\% were written in English and generally published outside of Quebec, though a few (about 20\%), such as the joint publications by McGill-Queen's University Press, were published in Quebec. These figures indicate the extent to which the issues of nationalism, independence and the referendums were being discussed in Quebec rather than the rest of the country, and in French rather than in English, a finding that is supported by earlier research such as Trépanier's (2001) analysis of sovereignist discourse, which concluded that separatist texts were addressed to Quebecers by Quebecers.

Only a small percentage of the 1,200 works in the corpus were translated from one official language to the other: 27 English works were translated into French, while 53 French works were translated into English. In total, 51 English translations were published, since two French volumes were abridged into a single English translation on two occasions. In addition, the corpus contains seven anthologies of thematically organized English translations of French texts culled from various sources - translations of selected works by Lionel Groulx (1973), André Laurendeau (1973; 1976), and Hubert Aquin (1988), for instance, or translations of selected National Assembly debates (Bergeron, Brown et al. 1980) and submissions to the Bélanger-Campeau commission (Fidler 1991). Interestingly, no similar French-language anthologies were found in the Library and Archives Canada catalogue during this period. These collections of English target texts will be referred to as "English-language anthologies" throughout this paper.

Finally, about one hundred pairs of works in the corpus of 1,200 texts are best described as bilingual, since they were published in both French and English (often with both languages in the same volume) but did not indicate which was the source text and which the target. In addition, the translator's name was often not specified, which was not the case in the 27 French translations and the 51 English translations. These "bilingual" works, however, will not be discussed further in this article, since it is virtually impossible to determine which of the texts was the source, and which was the target, making comparisons with the other translations very difficult.

\section{Narrative Frames}

In Translation and Conflict, Mona Baker proposes studying translation through the lens of narratives, which she defines as "public and personal 'stories' that we subscribe to and that guide our behaviour" (Baker 2006: 19). Narratives, the "inescapable mode 
by which we experience the world" (Baker 2006: 169), are constructed by human beings to make sense of reality, and they guide human behaviours and interactions. People make sense of experience mainly by putting it in the form of narratives (Riessman 1993: 4; Baker 2006: 169; Somers and Gibson 1994: 38), using stories to relate their experiences and interpret the world around them. Thus, narratives differ from person to person and from one group (community, nation, family) to another.

In Baker's approach to narratives, which is held by others as well (for example, Somers and Gibson 1994), "social life is itself storied and narrative is an ontological condition of social life" (Somers and Gibson 1994: 38; italics in the original). In this view, narratives affect all aspects of human life, and are not just literary, folk or fairy tales: all events or actions must be subjectively understood and communicated from one person to another through narratives.

The way narratives are interpreted depends not just on the narratives circulating in the reader's sociocultural situation; ${ }^{3}$ it also depends greatly on how these narratives are framed. This is because frames define the limits of the narrative and set it apart from its surroundings (Young 2004: 185). Framing functions in two ways: first, it can set the status of a narrative and second, it can disclose an attitude toward it (Young 2004: 77). Thus, frames are used to indicate that a work in the corpus is, for instance, a political analysis, biography or diary, and that it is objective or subjective, separatist or federalist, relevant or irrelevant to the current political situation, and so forth.

According to Baker (2006: 106), framing is an "active strategy that implies agency" and a way for us to "consciously participate in the construction of reality." Baker (2006: 107) stresses that the same set of events can be framed in different ways to "promote competing narratives." Consider, for instance, the contrasting labels used to describe one of the authors in the corpus, Pierre Vallières, in the paratexts that accompany his essays and their translations. He is a "political prisoner" in both his introduction to Nègres blancs d'Amérique (Vallières 1968: 11) and the biography that accompanies The Assassination of Pierre Laporte (Vallières 1977: 191). Parti Pris describes him as a "patriote québécois" (Vallières 1968: 541), while Monthly Review Press refers to him as a "revolutionary socialist" in a publisher's afterword to White Niggers of America (1971: 282). Each of these labels influences how Vallières will be perceived by readers and helps to shape the narratives that follow or precede the label, encouraging, for instance, sympathy, support, or approval from readers.

Paratexts like the ones prepared for Vallières' works are one form narrative frames can take. Genette (1987/2002) uses the term paratext to refer to elements that accompany, surround, prolong, and present a work, helping to ensure the latter is received and consumed in a certain way (Genette 1987/2002: 7). Paratexts can comment on or self-criticize the text (Crisafulli 1996: 92) and can include such elements as prefaces, notes (in the form of footnotes or endnotes), illustrations, advertisements, blurbs, and even titles or subtitles (Genette 1987/2002; Crisafulli 1996: 92). Such types of paratexts, which are found around the text but within the same volume, are referred to as peritexts, while paratexts found outside the text - interviews, correspondence, and reviews, for instance - are referred to as epitexts (Genette 1987/2002: 10-11).

To help answer the question of how and why TL readers were encouraged to read translations of texts related to the Quebec sovereignty referendums, this paper will analyze paratexts from the translations in the corpus. Only those paratexts that were new - that is to say written specifically for the target text and not appearing in any 
previous source edition - will be explored in detail. This decision was made because the new paratextual material in the target texts is likely to directly address perceived target reader concerns or needs and recontextualize the translations for an audience that was sometimes criticized, and often not directly addressed in the source edition. Perceptions and representations of both the source and target audiences can be gleaned from these new paratexts, as this paper will demonstrate.

Given that the corpus contains more than 75 translations into French or English, and that every translation contains some type of new paratextual material (for example, new book covers, titles, prefaces, promotional blurbs), not all of this material can be examined here. This paper will therefore focus on just two types of new peritexts: prefatory material and publisher's peritexts. Prefatory material refers to a text that precedes or follows the main body of a work (for example, preface, foreword, postscript) and through comments or criticisms, helps ensure the main body is received and consumed in a certain way (Genette 1987/2002: 7; Crisafulli 1996: 92). Prefatory material can be written by the author or translator, or by a third party such as politicians and scholars ${ }^{4}$ to address readers and attempt to explain how and why the work should be or should have been read (Genette 1987/2002: 241-242). Publisher's peritexts consist of those paratextual elements that are the responsibility of the publisher and appear within the work itself. These elements include the format of the work (for example, pocket or oversized edition), the cover (for example, hardback, paperback), the collection to which it belongs (for example, Typo Essai), the cover pages, and the unnumbered title pages, which may contain the title, information about the number of copies printed, and lists of other works published in this collection (Genette 1987/2002: 21-37). Again, due to the size of the corpus, this paper will focus on certain publisher's peritexts, namely biographical material about the author or translator and series notes appearing on the unnumbered pages immediately before or after the main body of the work.

\subsection{Positioning techniques in the prefaces and publisher's peritexts}

Roughly half of the English and French translations had new prefatory material or publisher's peritexts: these elements could be found in 23 of the 51 English target texts and 14 of the 26 French target texts. By contrast, all seven English-language anthologies contained new peritexts, and most had more than one: a total of 13 prefatory texts - but no publisher peritexts - were found in the English-language anthologies. $^{5}$

These new prefatory texts and publisher's peritexts generally serve several functions: they narrate (historical) events, provide (auto)biographic details about authors, translators or publishers, interpret the text for TL readers, and justify why the work should be read. These functions are best illustrated by studying a framing technique Baker refers to as positioning of participants, which refers to the way participants of an interaction are positioned - or position themselves - in relation to one another and outsiders (Baker 2006: 132). This technique, adopted frequently in the peritextual frames, is one way to establish trust with intended readers and show how the source language (SL) author, SL groups, or the translation itself is relevant to the TL readers. For instance, the achievements of the author or translator can be highlighted to show why he or she is particularly qualified to write or translate the work, while bio- 
graphical or other details can be included based on their relevance to the TL audience. In the corpus paratexts, the positioning technique is adopted for various purposes, including reassuring TL readers, demonstrating the work's uniqueness, promoting the work as a resource for better understanding other Canadians, encouraging debate/dialogue among Canadians, acknowledging that TL readers will likely find the work provocative, and re-appropriating the work for a cause TL readers support. Although the next sections will examine each of these positioning strategies in turn, many prefatory texts and publisher's peritexts use several strategies at once.

\subsubsection{Reassurance}

One way both the French and English paratexts try to position the translations is by reassuring readers either that the work is not separatist or pro-independence and that the author is open-minded about Canada (in the English translations), or that the source text (ST) authors are open-minded toward Quebecers and willing to consider compromises (in the French translations).

Consider, for instance, the publisher's Foreword to the English translation of Christian Dufour's Le défi québécois, which stresses that the upcoming work is "not a 'separatist' book" (Dufour 1990: 10). Or the Preface to the English Edition prepared by ST author Claude Morin, which appears in Quebec versus Ottawa: The Struggle for Self-government, 1960-1972 (a book containing translations of both Le pouvoir québécois... en négociation (1972) and Le combat québécois (1973) by Morin), and emphasizes that "[c]ontrary to what some might expect, my two books [...] do not constitute a plea for Quebec independence" (Morin 1976: xi). Likewise, Hugh MacLennan assures English-Canadian readers in the Foreword to the English Edition he wrote for Quebec Year One, a translation of Solange Chaput-Rolland's Québec année zero (1968), that although reviewers describe Chaput-Rolland as unreasonable and even oblivious to "the great reservoir of clumsy goodwill" in English Canada, she had in fact "been spending several months of every year travelling, lecturing and explaining Quebec from St. John's to Victoria, [so] she must have had a great deal more love for Canada than her exasperated words sometimes showed" (ChaputRolland 1968: 8). Chaput-Rolland's friendship with late English-Canadian author Gwethalyn Graham is offered as further proof of the SL author's openness to the TL community (Chaput-Rolland 1968: 8). Two years later, in a translation of another work by Chaput-Rolland, Douglas Fischer positions her in a similar manner, telling readers that the "pan-Canadianism" running though the work is due to "the determination of Madame Chaput-Rolland to understand and, where she cannot understand, to feel Canada, to reach out to all of us" (Chaput-Rolland 1970: 10).

For Francophone readers, ST authors are positioned in several ways. Some paratexts emphasize that the text is not trying to make Quebecers change their opinions or behaviour. Reed Scowen, for instance, in his Avant-propos à l'intention des lecteurs de la version française, states that "mon livre n'a pas pour but d'aider les Québécois à décider de leur avenir" and "[j]e tiens tout de suite à rassurer les lecteurs francophones: cette traduction ne cherche aucunement à modifier leur comportement" (Scowen 1999: 7). In other cases, the English-speaking ST author or various SL groups are positioned in a way that shows how they and the French-speaking TL readers are not as different as one might expect. In André Bruelle's Préface to Trente millions de mousquetaires: un Canada pour tous les Canadiens, the ST author, Gordon Gibson, 
is said to be pragmatic rather than dogmatic and "fermé au droit à la différence du Québec" (Gibson 1996: viii). In a similar vein, Léon Dion's preface to Le Canada face à son destin describes the English-language writers in the anthology as being without "le moindre soupçon de dogmatisme fédéraliste, ni la moindre trace d'arrogance ethnique. [...] il est partout évident que l'on considère les Québécois comme des frères amis et qu'on ne veut rien d'autre que de les comprendre et de les rendre à l'aise au sein du Canada" (Simeon 1978: viii). In these cases, the authors are depicted as openminded individuals who are not opposed to accommodating Quebecers or working out a compromise to the current form of federalism.

In both the English and French translations, when reassurance positioning techniques are used, the paratexts implicitly assure TL readers that the ST authors are open to the Other rather than focused on issues that only SL readers would find relevant and interesting.

\subsubsection{Uniqueness}

One way for a translation to be given value, particularly when a large number of publications on a similar subject are already available, is to position the target text as unique. This technique is found in nearly half the French prefatory texts and in two of the English-language anthologies. Almost no English target texts are positioned in this way, but this discrepancy is understandable: as discussed, about 70\% of the 1,200 works published on topics of Quebec nationalism, independence movements, and the referendums are originally written in French rather than English. Since a significant number of works are already available to French-language readers, translations are positioned as unique to stand out from the rest: readers are told they are being offered a perspective not necessarily available in the works originally written in French.

Several examples from the paratexts included with the French target texts should suffice: in the Préface à l'édition française in Tradition, modernité et aspiration nationale de la société québécoise (Guindon 1990: vii-xii), readers are told by Pierre Dandurand and Louis Maheu that while Guindon's line of thought is anchored in the tradition of Quebec social sciences, it also "s'en distancie de différentes façons et souvent dans une prise de position critique" (Guindon 1990: ix), making his book different from social science texts written by other Francophones. In Des comptes à rendre: Le Canada anglais et le Québec, de la Conquête à l'accord de Charlottetown, ST author John Conway is described by sociologist Guy Rocher as being original “dans l'explication qu'il apporte de l'enfermement des Canadiens français à l'intérieur des frontières du Québec" (Conway 1995: préface). Likewise, ST author François Moreau (1995), in the French translated text (TT) Le Québec, une nation opprimée, is said to offer "une autre vision de la lutte pour l'indépendance du Québec" (Moreau 1995: 8), while the introduction to Alain-G. Gagnon's Québec: état et société, prepared by the author himself, notes that "[c]ontrairement aux autres travaux sur la politique québécoise, le collectif que nous proposons ici met à contribution des chercheurs d'universités anglophones et francophones, de même que des chercheurs québécois du Canada hors-Québec" (Gagnon 1994: 20).

Two other French TTs are positioned in a related way: in both cases, emphasis is placed not on how the author or work is unique in comparison to the target culture, but instead on how the author differs from others in English Canada. Guy Rocher 
repeatedly emphasizes in the Préface to Des comptes à rendre that the author is not like the majority of English-Canadians:

[...] là où John Conway est original et en rupture avec son milieu, c'est qu'il perçoit comme normales et justifiées ce qui paraît à presque tous les Canadiens anglais comme des demandes exagérées et exaspérantes de la part du Québec. (Conway 1995: préface)

Similarly, the English source text Thirty Million Musketeers: One Canada for All Canadians is lauded because:

[...] nageant de nouveau à contre courant, [Gordon Gibson] publiait, en pleine campagne référendaire québécoise, Thirty Million Musketeers, un essai percutant qui claimait $[s i c]$ haut et fort la faillite du statu quo et tentait d'imaginer sur de nouvelles bases l'avenir du Canada avec le Québec. (Gibson 1996: vii)

As these quotations illustrate, the works that are positioned as being somehow unique target various segments of the French-speaking audience. In the first set of examples, the paratexts target an academic or politically aware readership, who may be interested in reading the works by Guindon or Gagnon, for instance, but who need reasons why works like these are unique enough to merit attention. Yet the paratexts also target a wider audience that does not support the political status quo in Canada. In these cases, Anglophone ST authors like John Conway are applauded for their open-mindedness toward issues important to many French-Canadians. Distance is drawn between these English-language ST authors and "other" or "most" EnglishCanadians, who are depicted as less supportive of reconceptualizing the relationship between the provinces and the federal government.

\subsubsection{Understanding}

Another way the translations are frequently positioned is as a means for TL readers to improve their understanding of various issues. Readers are told that the translation has been published to help them understand something about the Other, whether this means Quebec, French Canada, English Canada or smaller segments of both. Once again, a few examples from the corpus will help illustrate this positioning technique.

Let's start with three French target texts. The Note de l'éditeur in Bercuson and Cooper's Goodbye et bonne chance! Les adieux du Canada anglais au Québec argues that given the then-current constitutional debates, "il nous est toutefois apparu d'une importance primordiale [...] de faire connaître le point de vue de nos interlocuteurs canadiens-anglais" (Bercuson and Cooper 1991: n.p.), while ST author Alain-G. Gagnon argues that one of the strengths of the essays in Québec: état et société is that they will help Quebecers become informed about rivalries between federalists and nationalists, socialist-democrats and neo-liberals, centralists and decentralists, Francophones and Anglophones, and Quebec Francophones and English-Canadians (Gagnon 1994: 20). Finally, Guy Rocher, in the preface to the French translation of John Conway's Debts to Pay, stresses that "la traduction française de ce livre mérite d'être lue et méditée comme un précieux témoignage d'amitié et de compréhension que nous apporte un vent favorable venu de l'Ouest" (Conway 1995: préface).

Although the understanding positioning technique is found in French prefatory texts and publisher's peritexts like those in Conway (1995), Gagnon (1994), and Bercuson and Cooper (1991) referred to above, the technique is much more common 
in the English prefatory texts, which offer a wide range of reasons why a work would help further understanding. Quotations from a few of the more than a dozen examples should suffice:

You would be taking a superficial view if you believed the new consciousness of Quebec involves an outburst of long-repressed hatred towards you: between the old images and the new ones forming, the usual meetings have become difficult. We can believe no longer, as the champions of entente so often tell us, that we have only to accept our differences and discover ourselves as we are. Since we decided to cease being what we were, it is comprehension of what we want to be that is required of you. (authorial preface in Dumont 1974: xii; my emphasis)

To help the English Canadians to comprehend the depth of the ongoing crisis, and to appreciate the way the people of Québec see the situation, this translated and expanded version of La prochaine révolution has been prepared. (Foreword by Hugh Thorburn in Dion 1976: xi)

I hope that English-language publication of this synthesis of historical ideologies in Quebec will contribute to a better understanding of Québécois demands, and encourage a search for a solution that will result in harmonious relations between Quebec and Canada. (authorial preface in Monière 1981: vii-viii)

"Sovereignty-association," whether it succeeds or fails, is a crucial issue which must be understood by all Canadians. This is why Dr. Lallier's reflections merit to receive the most serious consideration. (Preface by the Hon. Pierre Sévigny in Lallier 1991: n.p.)

It may be difficult to feel this movement outside of Quebec, but I can assure you that it is tremendous. One should be aware of it if only to try to understand what will happen in the next few years. (authorial preface to the English edition in Bourgault 1991: n.p.)

As a critical examination of the main identity narratives that have shaped Quebec's self-image since the 1950s and as an exploration of how this identity can be imagined differently, this book can perhaps help to clarify some aspects of Quebec's past and contemporary identity. (authorial preface to the English edition in Maclure 2003: xv)

Another English target text contains a peritext that emphasizes not only understanding, but also open-mindedness. In the foreword by Duncan Cameron to the Parti Québécois' pro-independence book Quebec in a New World, readers are told:

People of good will, whatever their ultimate conclusions about the merits of the positions exposed here, can only welcome the opportunity afforded to deepen their understanding of the aspirations of Quebec sovereignists. (Duncan Cameron's Foreword in Parti Québécois 1994: xiv-xv)

One implication to this statement is that English-Canadians who do not want to read the target text are impeding effective communication between a dissatisfied group of Canadians and the rest of the country.

The understanding positioning technique is found in polemical pro-independence works (for example, Parti Québécois 1994; Bourgault 1991), as well as in works not arguing directly for or against independence (for example, Monière 1981; Gagnon 1994). Not limited to a single decade, the focus on understanding is found in works published from the early 1970s (for example, Dumont 1974; Bergeron 1974) - and, with very few exceptions - until the early 1990s (for example, Bourgault 1991). This latter trend is interesting, as it coincides with the date of the last independence referendum. English-language readers are often encouraged to be open-minded and 
understanding toward Quebec's Francophones (whether separatist or not) so long as a referendum seems imminent. In fact, this shift in focus away from understanding after the early 1990s matches the larger trend found in the corpus: while Frenchlanguage publications of works related to nationalism, independence movements, and the Quebec referendums decrease after 1995 but remain stable in the post-1995 referendum period, English-language publications declined steadily from 1996 to 2000. It is as if, once the No side had won a second time, English-speaking Canadians saw little need to continue discussing or understanding the issues that were not yet considered resolved in Quebec; the positioning technique in the prefatory texts and publisher's peritexts reflects this larger trend.

The assumption by those who adopted this positioning strategy seems to be that English-Canadians knew very little about (or were completely indifferent to) why some French-Canadians were unhappy with the current federal structure. The translations were framed as a way for these Anglophone readers to gain new insight about these issues. In fact, this lack of knowledge is directly mentioned in the prefatory material included in the English editions of Chaput-Rolland's Regards 1969: La seconde conquête (1970), Dion's La prochaine révolution (1976), as well as the English anthologies The Question: The Debate on the Referendum Question, Quebec National Assembly, March 4-20, 1980 (Bergeron, Brown et al.1980) and Canada, Adieu? Quebec Debates its Future (Fidler 1991):

This is written in the fourth week of the dragging crisis launched by the FLQ kidnappings. What can English Canadians know, rationally or intuitively, of what it means for Quebec and for a writer like Madame Chaput-Rolland? (Chaput-Rolland 1970: 10)

Unfortunately, these developments [Quiet Revolution] are not sufficiently perceived and understood in English Canada, where the Québec concept of a Canada of two nations, English and French, stands discredited and forgotten. There is no appreciation of the French-Canadian felt need for protective constitutional structures, to make up for their minority status. If this unawareness and indifference persist in English Canada, the situation is bound to deteriorate and lead at last to a dramatic confrontation. (Dion 1976: xiii)

Canadians outside Quebec have often been unaware of the significance and the intensity of the debate [on the referendum question] in the province. They have not realized what profound questions are at stake. (Bergeron, Brown et al. 1980: 3)

Our present lack of knowledge and understanding erodes the ties that bind us together as a country, leaving us vulnerable to prejudice and unaware of the benefits we risk losing through inaction or indifference. The simple fact is that we can no longer afford the luxury of remaining complacent, oblivious to what is happening in other parts of this enormous country. (Fidler 1991: ii)

The works, then, are positioned as sources of understanding to help combat what is believed to be a lack of comprehension on the part of English-speaking Canadians. By contrast, this same technique is not typically adopted in the French-language target texts. This tendency, though, may be part of a larger trend in English-Canadian paratexts in the late twentieth century. In fact, Sherry Simon's (1989) study of translation in Quebec notes that, at this time, prefaces to English translations of FrenchCanadian novels often situate the translation within a political and ethnographic context and express a belief that "se traduire aide à se comprendre et donc à se rapprocher culturellement et politiquement" (Simon 1989: 35). 
Another factor that could have contributed to the emphasis on understanding in the English paratexts is the way translation is valued in French and English within Canada at this time. Simon notes the following:

When languages are of unequal cultural status, the direction of translation dictates the value of what will be discovered. The "discoveries" of translation can be both positive and negative. Translating "up" (into a dominant language) is welcomed. It expresses values of curiosity and universality. Translating "down" (into the "minor" language) elicits more complex reactions. It can lead to discoveries that are not necessarily positive, which reveal the oppressive and forced character of language exchange. Writers of self-perceived minority languages are hesitant to seek out foreign works before they have shored up their own defences and proven the viability of their own literary language. (Simon 2006: 40)

The trend here seems to follow the phenomenon Simon is describing. In this case, the English target texts are "up" translations, and the paratext writers are urging understanding from English-speaking readers because they comprise the dominant language group in Canada and can therefore be more accommodating. The emphasis on understanding is not found in the French target texts because these are "down" translations, from the dominant official language into the less dominant. Interestingly though, because of the subject matter of the corpus works, the dominant/minority position is not quite the same as it might be with texts like novels or administrative documents. Here, Quebec - and French Quebec in particular - is the main sender and receiver of texts about Quebec nationalism, independence movements, and the referendums - as evidenced by the number of works published in French in Quebec compared to the number published in English outside the province - meaning that French is, in a sense, the "dominant" language in which such topics are discussed. The English-language paratexts seem to agree with this point, given the number of prefaces and publisher's peritexts that emphasize how little Englishspeaking Canadians know about these three topics in particular, and about Quebec in general. However, the fact that the peritexts also encourage English-language readers to be open-minded and understanding shows that French Quebec is seen in both a dominant and minority role at the same time: French-speaking Quebecers need to be understood, because they are a dissatisfied minority group in Canada, but at the same time, Francophone Quebecers are the most knowledgeable about Quebec nationalism, independence movements, and the referendums and therefore have much to teach Anglophones, who are in a weaker position in terms of information. This may not necessarily be the case, but the paratexts that focus on understanding evidence this assumption about Anglophones and Francophones in Canada.

\subsubsection{Debate and Dialogue}

While fewer works are positioned as a source of debate and dialogue than as a source of understanding, this framing technique still occurs fairly frequently in both the French and English translations. And unlike the understanding argument, the emphasis on debate and dialogue is found throughout the 1968-2000 period: translations from the mid-1970s until 2003 position works in this way. Moreover, many works that express an intention of increasing understanding among Canadians also stress a need for dialogue and debate. 
Côté and Johnson, in their preface to the English TT If Quebec Goes, assert that their book was written based on the assumption that "public, reasonable debate should guide collective decisions" (Côté and Johnson 1995: xi). Dion, in an authorial preface, emphasizes his intention that his work will "evoke interest and response among non-francophone readers" (Dion 1976: ix), while the publisher's foreword in the English translation, A Canadian Challenge - Le défi québécois, remarks that the book has been published to "introduce Dufour's questions to the public debate of issues that include [...] the Meech Lake Accord" (Dufour 1990: 9). In another case, ST author Jocelyn Maclure argues that because the English target text Quebec Identity: The Challenge of Pluralism may help clarify some aspects of Quebec's past and current identity, it might "remove some unnecessary impediments to the restoration of a constructive dialogue between Quebec and the rest of Canada" (Maclure 2003: xv). Finally, Duncan Cameron's foreword to Quebec in a New World, the English translation of the Parti Québécois plan for independence, acknowledges that "reaction outside Quebec to what is being presented here will not be without significance. The initial response is likely to cover the spectrum from astonishment to frustration, to indifference and disbelief, but some will want to engage in a dialogue with the PQ" (Cameron 1994: xiv). It then promises that "there is much material here for debate" (xiv-xv). In this example, the foreword anticipates TL reader objections to the work and provides them with a reason to read the translation, even if they disagree fundamentally with the PQ platform.

In the two French TTs that use this framing strategy, one preface, prepared by Léon Dion for Le Canada face à son destin, argues that the work will be part of the on-going debate on sovereignty-association (Simeon 1978: x), while the other, prepared by Pierre Dandurand and Louis Maheu for Tradition, modernité et aspiration nationale de la société québécoise, states that the work should offer some readers the opportunity for dialogue and others the opportunity to debate (Guindon 1990: xii).

This emphasis on debate and dialogue represents a strategic positioning decision by the authors, translators, and other agents. It is a way of anticipating the reactions of TL readers and convincing them to read a controversial work with a potentially frustrating or unappealing thesis. In all of the examples from the English target texts, the assumption about TL readers seems to be that they would be unreceptive to ideas emanating from Quebec. However, both the English and French paratexts with this framing strategy position the translations as fodder for debates and discussions among Canadians.

\subsubsection{Provocation}

In some cases, the translations are simply positioned as provocative material: the writers of the prefatory and publisher's peritexts openly acknowledge that TL readers will likely consider the work provocative and disagree with its thesis. As with other positioning strategies, readers are told to pick up a controversial work because it will challenge their traditional beliefs about Canada, implying that doing so will demonstrate their open-mindedness or interest in understanding more about Canada's other official language group. In fact, some texts that are positioned as sources for understanding the Other also emphasize the provocative nature of the work.

In his foreword to Reflections II: The Second Conquest (Chaput-Rolland 1970), Douglas Fisher advises Anglophone readers that Chaput-Rolland will jar readers' 
complacency "if you tend to think that the skeptical feelings of French Canadians about us and Canada as we conceive it do not run deep or that they will quieten and phase themselves out in a pleasant accommodation to the majority will in Canada" (Chaput-Rolland 1970: 7). Similarly, Hugh Thorburn tells English-speaking readers that Léon Dion's Quebec: The Unfinished Revolution will “serve to awaken EnglishCanadians to the continued existence of a challenge to the national accommodation that they thought had been secured with the election of the Trudeau government" (Dion 1976: xiv), while Rod Dobell, in the foreword to Canada Adieu: Quebec Debates its Future, expects that "most readers of this compilation will find some of the views expressed here challenging, and some possibly downright infuriating” (Fidler 1991: ii).

The provocation positioning strategy is found only in the English target texts and anthologies, but not in the French target texts. Based on the comments in the paratexts, English TL readers are expected to be unreceptive to the translations either because of their preconceived ideas about French-speaking Quebecers and referendum-related issues, or because they do not see a problem with Canada's form of federalism. By positioning the target text as a provocative work, the paratexts are trying to directly address perceived reader concerns. However, it is intriguing that only Anglophones are seen as hostile to ideas expressed by SL authors: since no French-language TTs are positioned as provocative, Francophones are evidently not expected to be offended by the translations they are offered. This finding is in line with the conclusions of the uniqueness positioning strategy, where it is clear that a number of French TTs support opinions that match those of a large number of French-speaking Quebecers (namely changes to the status quo in Canada) but are not necessarily in favour of complete independence. Because many of the translated works support changes to the current form of federalism, the targeted Frenchspeaking readers are expected to be receptive to these ideas and therefore the provocation position strategy has not been adopted.

\subsubsection{Reappropriation for another cause}

A final framing technique, albeit one used very infrequently, is to position the translation as a text particularly relevant to a cause supported by the TL readers. This strategy is found in one English TT - Léandre Bergeron's Why There must be a Revolution in Quebec (1974) - and one English-language anthology - Beyond the PQ: The National Struggle and the Quebec working class (1980). Let's look at each of these in more detail.

The publisher's note to Why There Must be a Revolution in Quebec indicates that "NC Press publishes books and pamphlets that will be of assistance in the Canadian People's struggle for national liberation" (1974: n.p.). Readers are further advised that "[a]ny portion of this book may be used free of charge by anyone serving the cause of Québécois or Canadian liberation or the cause of the working people in any country." The English translation also includes a new introduction prepared by Bergeron, in which he notes:

[...] I did not visualize an English translation, feeling that the discussion throughout the book was very specifically Quebec-based, and therefore could not be for others, [sic] the handbook that it was to be for many Québécois. But the editors of NC Press convinced me that by adding certain explanatory notes and modifying certain passages, Canadian workers in general would not only be able to see how things are developing in 
Quebec, but also apply to their specific situation the relevant content; since of course the fundamental contradiction is the same for both Québécois and Canadian workers. (Introduction by Bergeron 1974: 7; my emphasis)

[...] the national struggle going on in Quebec is not a struggle against Canadians but against a specific political structure that is alienating both Canadians and Québécois. We must keep in mind that the fundamental struggle is the same for both, the struggle against capitalists, local and especially foreign, U.S.-based since the latter are the big wheels of the system. (Introduction by Bergeron 1974: 8)

My hope is that this translation of Pourquoi une révolution au Québec will help Canadian workers and students understand Québécois workers so that the common interests of both will be a uniting force against our common enemy, American imperialism. (Introduction by Bergeron 1974: 8; my emphasis)

Clearly, this is an instance in which the values and ideas of the TT publisher and the ST author are very similar. The translation has been positioned in a way that makes it relevant to socialist struggles supported by the publisher and the target readers.

In the second example, Beyond the PQ. The National Struggle and the Quebec Working Class, both a new preface and a new introduction for the English translation show a positioning strategy similar to the one in Bergeron (1974). As the preface indicates:

The following articles are translations of documents from the Centre de Formation Populaire. We believe these articles are of vital importance to the English Canadian working class. (Centre de formation populaire 1980: 1)

[...] the national aspirations of the Quebec people are not directed against English Canadian workers but rather, on the contrary, are directed against the common enemy of both French and English speaking workers, namely the Canadian bourgeoisie and their U.S. Allies. (Centre de formation populaire 1980: 1)

The introduction, much lengthier than the preface, builds on this idea and explains how activists in Quebec are fighting for a cause that will benefit Englishspeaking TL readers in the rest of the country:

[...] we must learn to take advantage of any situation which will weaken bourgeois dominance, and to resolve any political or economic crisis which will provide a net gain for the popular movement. The present political crisis in Quebec presents such an opportunity. (Centre de formation populaire 1980: 3; my emphasis)

The present struggle in Quebec poses no threat to the working class in English Canada or to its allies, actual or potential, among the urban poor, agrarian petite bourgeoisie, native people or other exploited minorities. In fact, the people of Quebec are in the forefront of a struggle which can benefit all of us. (Centre de formation populaire 1980: 6; my emphasis)

We should join with our brothers and sisters in Quebec in demanding profound changes in the constitutional arrangements in this country. Whether Quebec remains in Canada under a new constitution, or opts to go on its own is a secondary question for the working class in the rest of the country. We must extend and build the struggle against monopoly capitalist and imperial control of the Canadian state and demand a more equitable democratic constitution while preparing for the day when we can put socialism squarely on this country's agenda. (Centre de formation populaire 1980: 6; my emphasis) 
Here again is a set of peritexts that frame the accompanying texts as relevant to a struggle in which English-speaking Canadians are engaged, even though these texts were initially written to inspire action specifically from French-speaking Quebecers. The frames reposition the collected texts as activist works that should inspire action on the part of English-speaking readers, making them relevant to the TL readers.

\section{Conclusions}

The prefaces and publisher's peritexts in the corpus translations provide a glimpse of how English- and French-speaking Canadians were perceived and targeted with respect to an issue that has been contentious in Canada: Quebec independence. Since French Quebec is the main producer and receiver of texts related to the referendums, it is probably not surprising that the positioning strategies used in the prefaces and publisher's peritexts depict English-Canadians as having a more limited understanding of the political views of French-speaking Canadians than vice versa. According to these paratextual frames, Anglophones do not understand the reasons, emotions, and arguments behind the independence movement and the sovereignty referendums. And, because the prefatory texts make frequent references to understanding, open-mindedness, and open dialogue, English-Canadians are being urged to be more accommodating to points of view commonly held by various French-Canadian groups, including a need for renewed federalism, sovereignty-association, or a different relationship between Canada and the provinces.

The fact that a work is positioned as a means of understanding the Other, however, does not mean that it will actually be received as intended. In fact, this strategy may not actually attract any of those readers who are unlikely to pick up the book in the first place: those who are very hostile to the idea of Quebec independence and nationalism are unlikely to be convinced by the argument to be more open-minded. In a way, the prefatory and publisher's peritexts that emphasize comprehension are merely reaching those English-speaking readers who already want to learn more about the issues. The positioning strategies that focus on dialogue, debate, provocation, and activism may be more effective techniques, as they at least address and acknowledge the potential concerns of TL readers.

In short, the English prefaces and publisher's peritexts tend to emphasize communication and understanding among Canadians, arguing that English-Canadians are not as knowledgeable about Quebec nationalism and independence movements as Quebecers. The French paratexts tend to emphasize the uniqueness of the translation, offering readers a narrative that differs from other English-Canadian works, but which is often similar to narratives already available in French. However, these paratexts are depicting an imagined relationship between the two linguistic groups, as these views do not consider the many Anglophones who have researched and written about Quebec nationalism, independence movements, and the referendums, nor do they account for the many bilingual Canadians who can read both English and French. Moreover, they offer a limited picture of Canada, as understanding may be something generally lacking among Canadians, due to the public narratives circulating in the media. A 1978 study, for instance, determined that English-Canadian newspapers prioritized news about politics, crime, and labour disputes, providing almost no coverage of economic, social, and cultural events happening in Quebec, 
while French-language newspapers gave news occurring outside Quebec very low priority (Simpson 1978). Likewise, national news programs on Canada's official-language, public-service broadcasters CBC and Radio-Canada in the late 1980s and early 1990s described sovereignty-related events like the Meech Lake and Charlottetown Accords differently, using seemingly interchangeable terms like distinct society and société distincte in diverging ways (Conway 2011).

And so, even if Anglophones are indeed less knowledgeable than Francophones about events in Quebec, the inverse is likely also be true: Francophone knowledge of English-Canadian feelings toward Quebec nationalism, independence movements, and the referendums is likely to have been limited. However, the paratexts do not address this point. Moreover, French prefatory peritexts show a clear emphasis on the fact that the English ST differs from what TL readers might have expected of English-Canadians. With the exception of Simeon (1978), where the authors are said to represent the opinion of the English-Canadian elite, no work is positioned in the French-language peritexts as a "typical" example of the point of views common to most English-Canadians. Instead, the ST author's openness to compromise is highlighted for Francophone readers, who are often offered works that conform to widely held TL political positions (renewed federalism, reconceived relationship between the provinces and the federal government). It seems, then, that English-speaking Canadians are frequently expected to be more open to compromise, while Frenchspeaking Quebecers are not, though as the threat of Quebec sovereignty receded after the 1995 referendum defeat, English publications and translations on Quebec nationalism, independence movements, and the referendums declined rapidly, while the prefaces and publisher's peritexts with an understanding positioning strategy disappeared almost entirely.

\section{NOTES}

1. Consider, for instance, Reed Scowen's Time to Say Goodbye: The Case for Getting Quebec out of Canada (McClelland \& Stewart, 1999), which, as Scowen acknowledges in the preface to the French edition, is addressed to all Canadians except Quebecers, or Mordecai Richler's Oh Canada! Oh Quebec! Requiem for a Divided Country (Penguin Books, 1992), which ridicules Quebec's language and sign laws and denounces the anti-Semitic comments made by French-Canadian nationalists in the 1930s and 1940s. Both of these works were translated into French.

2. The Clarity Act, which was assented to on June 29, 2000, stipulates that in the event of another referendum, the House of Commons must consider the question put to voters and determine, within thirty days, whether this question is clear. In the event that the House of Commons decides it is unclear, the federal government is under no obligation to negotiate with Quebec.

3. Various types of narratives circulate in a society. Personal (or ontological) narratives are stories a person uses to make sense of and act in his or her life (Somers and Gibson 1994: 61), and to relate his or her history and place in the world (Baker 2006: 28). Public narratives are those "attached to cultural and institutional formations larger than the single individual, to inter-subjective networks or institutions" (Somers and Gibson 1994: 62); they are developed by and circulating within families, religious/literary/cultural institutions, the media, a nation, and so forth (Baker 2006: 33). Conceptual narratives are circulated and generated by researchers in a given field of study (Baker 2006: 39); they may be circulated by a single scholar in a particular field (much like a personal narrative), or may instead be widely circulating among many researchers (much like a public narrative). Finally, metanarratives operate on a scale larger than a single country or culture. All theories and concepts, indeed all other narratives, are "encoded with aspects of these master narratives," although we may be completely unaware of their influence (Somers and Gibson 1994: 63). However, the boundaries between these categories shift and blur: conceptual narratives, for instance, can slip into the public sphere when a story begins to circulate in the media. 
4. Genette also discusses fictional prefaces that are attributed to fictitious persons, but no such prefaces were found in our corpus.

5. While these initial figures seem to indicate that a much higher percentage of the English-language anthologies contained new paratextual material, this is not actually the case. Since no Englishlanguage anthology had a corresponding French collection to which it could be compared, all prefatory material had to be considered new, because it was prepared specifically for the English TL readers. In the French and English target texts, by contrast, virtually all the target texts contained one or more prefatory and publisher's peritexts, but only half contained new prefatory and publisher's peritexts written specifically for the TL readers.

\section{REFERENCES}

BAKer, Mona (2006): Translation and Conflict: A Narrative Account. London: Routledge.

Brisset, Annie (1989): In Search of a Target Language: The politics of Theatre Translation in Quebec. (Translated by Lynda DAVEY) Target. 1(1):9-27.

Conway, Kyle (2011): Everyone says No: Public Service Broadcasting and the Failure of Translation. Montreal/Kingston: McGill-Queen's University Press.

Crisafulli, Edoardo (1996): The Translator as Textual Critic and the Potential of Transparent Discourse. The Translator. 5(1):83-107.

Genette, Gérard (1987/2002): Seuils. Paris: Éditions du Seuil.

Gill, Robert M. (1995): The 1995 referendum: A Quebec perspective. The American Review of Canadian Studies. 25(4):409-432.

Ladouceur, Louise (2000): From Other Tongue to Mother Tongue in the Drama of Quebec and Canada. In: Sherry Simon and Paul ST-PIERRE, eds. Changing the Terms: Translating in the Postcolonial Era. Ottawa: University of Ottawa Press, 207-226.

MezeI, Kathy (1998): Bilingualism and Translation in/of Michèle Lalonde's 'Speak White.' The Translator 4(2):229-247.

Riessman, Catherine Kohler (1993): Narrative analysis. Newbury Park, California: Sage Publications.

Simon, Sherry (1989): L'inscription sociale de la traduction au Québec. Québec: Office de la langue française.

Simon, Sherry (2006): Translating Montreal: Episodes in the Life of a Divided City. Montreal/ Kingston: McGill-Queen's University Press.

Simpson, Jeffrey (20 July 1978): An analysis of the coverage by Quebec papers shows... French seldom read about the English. The Globe and Mail. 10.

Somers, Margaret R. and Gibson, Gloria D. (1994): Reclaiming the Epistemological "Other": Narrative and the Social Construction of Identity. In: Craig CALHoun, ed. Social Theory and the Politics of Identity. Cambridge/Oxford: Blackwell, 37-99.

TréPANIER, Anne (2001): Un discours à plusieurs voix: La grammaire du OUI en 1995. Laval: Presses de l'Université Laval.

VAllières, Pierre (1971): White Niggers of America: The Percocious Autobiography of a Quebec "terrorist." (Translated by Joan PINKHAM) New York: Monthly Review Press.

Young, Katharine (2004): Frame and boundary in the phenomenology of narrative. In: MarieLaure Ryan, ed. Narrative Across Media: The Languages of Storytelling. Lincoln/London: University of Nebraska Press, 76-107.

\section{APPENDICES: Corpus works with new prefaces or publisher's peritexts French to English translations}

Bergeron, Léandre (1972). Pourquoi une révolution au Québec. Montréal: Éditions québécoises. Bergeron, Léandre (1974). Why There Must Be a Revolution in Québec. (Translated by Sheldon LIPSEY) Toronto: NC Press.

Bourgault, Pierre (1990). Maintenant ou jamais! Montréal: Éditions internationales Alain Stanké. 
Bourgault, Pierre (1991). Now or Never! Manifesto for an Independent Quebec. (Translated by David Homel) Toronto: Key Porter Books Ltd.

Chaput-Rolland, Solange (1968). Québec année zero. Montréal: Cercle du livre de France.

Chaput-Rolland, Solange (1968). Reflections: Quebec Year One. (Translated by Gretta ChamBERS) Montréal: Château Books

Chaput-Rolland, Solange (1970): Regards 1969: La seconde conquête. Montréal: Cercle du livre de France.

Chaput-Rolland, Solange (1970): Reflections II: The second Conquest. (Translated by Gretta Chambers and Solange Chaput-Rolland) Montréal: Château Books.

Clift, Dominique and McLeod Arnopoulos, Sheila (1979): Le fait anglais au Québec. Montréal: Libre Expression.

Clift, Dominique and McLeod Arnopoulos, Sheila (1979): The English Fact in Quebec. (Translated by Sheila McLeod Arnopolous and Dominique Clift.) Montreal: Libre Expression.

Clift, Dominique (1981): Le déclin du nationalisme au Québec. Montreal: Libre expression.

Clift, Dominique (1982): Quebec nationalism in crisis. (Translated by Dominique ClifT) Kingston: McGill-Queen's University Press.

Côté, Marceland Johnston, David (1995): If Québec Goes... The Real Cost of Separation. Toronto: Stoddart Publishing.

CôTÉ, Marcel (1995): Le rêve de la terre promise: les coûts de l'indépendance. Montréal: Éditions internationales Stanké.

Delisle, Esther (1992): Le traître et le Juif: Lionel Groulx, le devoir et le délire du nationalisme d'extrême droite dans la province de Québec, 1929-1939. Outremont, Québec: L'Étincelle.

Delisle, Esther (1993): The Traitor and the Jew: Anti-Semitism and Extreme Right-Wing Nationalism in Québec from 1929 to 1939. (Translated by Madeline HÉBerT) Montréal: R. Davies Pub.

Dion, Léon (1973): La prochaine révolution. Montréal: Leméac.

Dion, Léon (1976): Québec: The Unfinished Revolution. (Translated by Thérèse Romer) Montréal: McGill-Queen's University Press.

Dufour, Christian (1989): Le défi québécois. Montréal: L'Hexagone.

Dufour, Christian (1990): A Canadian Challenge - Le défi québécois. (Translated by Heather PARKer) Lantzville, BC: Oolichan Books.

Dumont, Fernand (1971): La vigile du Québec. Octobre 1970: l'impasse?. Montréal: Hurtubise $\mathrm{HMH}$.

Dumont, Fernand (1974): The Vigil of Quebec. (Translated by Sheila Fischman and Richard Howard) Toronto: University of Toronto Press.

LAForest, Guy (1992): Trudeau et la fin d'un rêve canadien. Sillery, Québec: Septentrion.

Laforest, Guy (1995): Trudeau and the End of a Canadian Dream. (Translated by Paul Leduc Browne and Michelle Weinroth) Montréal: McGill-Queen's University Press.

LALLIER, Adalbert (1980): La souveraineté-association: réalisme économique ou utopie. Montréal: Cercle du livre de France.

Lallier, Aldabert (1991): Sovereignty Association: Economic Realism or Utopia? Oakville, Ont.: Mosaic Press.

Maclure, Jocelyn (2000): Récits identitaires: le Québec à l'épreuve du pluralisme. Montréal: Éditions Québec/Amérique.

Maclure, Jocelyn (2003): Quebec Identity: The Challenge of Pluralism. (Translated by Peter Feldstein) Montreal: McGill-Queen's University Press.

Mathews, Georges (1990): L’Accord: comment Robert Bourassa fera l'indépendance. Montréal: Le Jour.

Mathews, Georges (1990): The Quiet Resolution: Quebec's Challenge to Canada. (Translated by Dominique Clift) Toronto: Summerhill Press.

Monière, Denis (1977): Le développement des idéologies au Québec: des origines à nos jours. Montréal: Éditions Québec-Amérique. 
Monière, Denis (1981): Ideologies in Quebec: The Historical Development. (Translated by

Richard HowARD) Toronto: University of Toronto Press.

Morin, Claude (1972): Le pouvoir québécois... en négociation. Montréal: Éditions du Boréal Express.

Morin, Claude (1973): Le combat québécois. Montréal: Éditions du Boréal Express.

Morin, Claude (1976): Quebec versus Ottawa: The Struggle for Self-government, 1960-1972.

(Translated by Richard HowARD) Montréal: Éditions du Boréal Express.

PARTI QUÉBÉCOIS (1993): Le Québec dans un monde nouveau. Montréal: VLB.

PARTI QUÉBÉCOIS (1994): Quebec in a new world. (Translated by Robert CHodos) Toronto: J. Lorimer.

Ryan, Claude (1978a): Une société stable. Montréal: Éditions Héritage.

Ryan, Claude (1978b): A Stable Society. (Translated by Robert Guy Scully and Marc Plourde) Montréal: Éditions Héritage.

Vallières, Pierre (1968): Nègres blancs d’Amérique. Montréal: Éditions Parti Pris.

VAllières, Pierre (1971): L’urgence de choisir. Montréal: Éditions Parti Pris.

Vallières, Pierre (1972): Choose!. (Translated by Penelope Williams) Toronto: New Press.

Vallières, Pierre (1977): L'exécution de Pierre Laporte: Le Dessous de l'Opération Essai. Montréal: Éditions Québec-Amérique.

Vallières, Pierre (1977): The Assassination of Pierre Laporte. (Translated by Ralph Wells) Toronto: J. Lorimer.

Vallières, Pierre (1977): Un Québec impossible. Montréal: Éditions Québec-Amérique.

VAllières, Pierre (1980): The Impossible Québec: Illusions of Sovereignty-Association. (Translated by Jeffrey S. Moore) Montréal: Black Rose Publications.

Venne, Michel, ed.(2000): Penser la nation québécoise. Montréal: Éditions Québec/Amérique.

Venne, Michel, ed. (2001): Vive Quebec! New Thinking and New Approaches to the Quebec Nation. (Translated by Robert CHodos and Louisa BLAIR) Toronto: James Lorimer \& Co. Ltd.

\section{English to French translations}

Bercuson, David Jay and Cooper, Barry (1991): Deconfederation: Canada without Quebec. Toronto: Key Porter Books.

Bercuson, David Jay and Cooper, Barry (1991): Goodbye... et bonne chance: Les adieux du Canada anglais au Québec. (Translated by Claude FAFARD and Stephen Dupont) Montréal: Le Jour.

Conway, John F (1992): Debts to Pay: English Canada and Quebec from the Conquest to the Referendum. Toronto: James Lorimer.

Conway, John F. (1995): Des comptes à rendre: le Canada anglais et le Québec, de la Conquête à l'accord de Charlottetown. (Translated by Pierre R. Desrosiers) Montréal: VLB.

Desbarats, Peter (1976): René: A Canadian in Search of a Country. Toronto: McClelland \& Stewart.

Desbarats, Peter (1977): René Lévesque: ou, le projet inachevé. (Translated by Robert Guy SCulLY) Montréal: Fides.

Freeman, Alan and Grady, Patrick (1995): Dividing the House: Planning for a Canada without Quebec. Toronto: Harper Collins.

Freeman, Alan and Grady, Patrick (1995): Québec/Canada: Les enjeux de la division. (Translated by Gérard BoulAD) Montréal: Hurtubise HMH.

Gagnon, Alain G., ed. (1984): Quebec: State and Society. Toronto: Methuen.

Gagnon, Alain G., ed. (1994): Québec: État et société. (Translated by Stéphane Éthier, Sarah Fortin, Dimitrios Karmis and Michel Sarra-Bournet) Montréal: Québec/Amérique.

Gibson, Gordon (1995): Thirty Million Musketeers: One Canada for All Canadians. Toronto: Key Porter Books.

Gibson, Gordon (1996): Trente millions de mousquetaires: un Canada pour tous les Canadiens. (Translated by Torbert DуоттE) Vancouver: Fraser Institute. 
Guindon, Hubert (1988): Quebec Society: Tradition, Modernity and Nationhood. Roberta Hamilton and John L. McMullan, eds. Toronto: University of Toronto Press.

GuINDon, Hubert (1990): Tradition, modernité et aspiration nationale de la société québécoise. (Translated by Suzanne Saint-Jacques Mineau) Roberta Hamilton and John L. McMulLAN, eds. Montréal: Éditions Saint-Martin.

Horton, Donald James (1995): André Laurendeau: la vie d'un nationaliste, 1912-1968. (Translated by Mario Pelletier) Saint-Laurent, Québec: Bellarmin.

Horton, Donald James (1993): André Laurendeau: French-Canadian Nationalist, 1912-1968. Toronto: Oxford University Press.

Laxer, James and Laxer, Robert (1978): Le Canada des libéraux: Pierre-Elliott Trudeau et la survivance de la confédération. (Translated by Jean-Pierre Fournier) Montréal: Éditions Québec-Amérique.

Laxer, James and Laxer, Robert (1983): The Liberal Idea of Canada: Pierre Trudeau and the Question of Canada's Survival. Toronto: J. Lorimer.

Monet, Jacques (1969): The Last Cannon Shot: A Study of French-Canadian Nationalism, 18371850. Toronto: University of Toronto Press.

Monet, Jacques (1981): La première révolution tranquille: le nationalisme canadien-français, 1837-1850. (Translated by Richard Bastien) Montréal: Fides.

Moreau, François (1995): Le Québec, une nation opprimée. (Translated by Michel Mill) Hull: Vents d'Ouest. [Note: The English source text for this work was never published, due to Moreau's death. The French edition was translated based on Moreau's unpublished manuscript].

Morf, Gustave (1970): Le Terrorisme québécois. Montréal: Les Editions de l'homme.

Morf, Gustave (1970): Terror in Quebec: Case Studies of the FLQ. Toronto: Clarke, Irwin.

Scowen, Reed (1999): Le temps des adieux: plaidoyer pour un Canada sans le Québec. (Translated by Brigitte CHABERT) Montréal: VLB.

Scowen, Reed (1999): Time to Say Goodbye: The Case for Getting Quebec out of Canada. Toronto: McClelland \& Stewart.

Simeon, Richard (1977): Must Canada Fail? Montreal: McGill-Queen’s University Press.

Simeon, Richard (1978): Le Canada face à son destin. Québec: Presses de l’Université Laval.

\section{English-language collections [English translations of various French source texts]}

Aquin, Hubert (1988): Writing Quebec: Selected Essays. (Translated by Paul Gibson, Reva Joshee and Anthony Purdy), Anthony Purdy, ed. Edmonton: University of Alberta Press.

Bergeron, Marie-Hélène, Brown, Douglas and Simeon, Richard, eds. (1980): The Question: the debate on the referendum question, Quebec National Assembly, March 4-20, 1980. (Translated by Sheila Fischman) Kingston, Ont.: Institute of Intergovernmental Relations, Queen's University.

Centre de formation populaire (1980): Beyond the PQ: The National Struggle and the Quebec Working Class. Regina: NYC Magazine Inc.

Fidler, Richard, ed. (1991): Canada Adieu? Quebec Debates its Future. Lantzville, BC: Oolichan Books.

Groulx, Lionel (1973): Abbé Groulx: Variations on a Nationalist Theme. (Translated by Susan Mann Trofimenkoff and Johanne L'Heureux), Susan Mann Trofimenkoff, ed. Vancouver: Copp Clark Pub.

Laurendeau, André (1973): André Laurendeau: Witness for Quebec: Essays. (Translated by Philip Stratford), Philip Stratford, ed. Toronto: Macmillan of Canada.

Laurendeau, André (1976): The Essential Laurendeau. (Translated by Johanne L'Heureux and Richard Howard), Ramsey Cook and Micheal Behiels, eds. Vancouver: Copp Clark. 